\title{
FIFTH SESSION
}

\author{
Saturday, April 25, 1964, at 9:30 a.m. \\ BUSINESS SESSION
}

Pursuant to the notice of the meeting published in the January, 1964, issue of the American Journal of International Law, the business meeting of the American Society of International Law convened at 9:30 a.m. in the Chinese Room of the Mayflower Hotel, Washington, D. C. Mr. JAMES N. HYDE, President of the Society, presided.

Judge Edward Dumbauld, Secretary of the Society, read the list of members who had passed away during the year.

\section{In gigemotiam}

Elusworth C. Alvord, Washington, D. C., member since 1939, died January 16, 1964.

Albert MacC. Barnes, New York, N. Y., member since 1944, died January $21,1963$.

Simney N. BarnetT, New York, N. Y., member since 1952, died 1963.

Arthur Bassett, San Francisco, California, member since 1908, died November, 1962.

Ben Bruce Blakeney, Tokyo, Japan, member since 1954, died March 4, 1963.

Aueksander Bramson, Warsaw, Poland, member since 1960, died July 19, 1963.

HARvey H. Bundy, Boston, Massachusetts, member since 1936, died 1963.

HenRY F. Butler, Washington, D. C., member since 1939, died February $5,1964$.

Kenneth H. Campbell, Washington, D. C., member since 1956, died March 24, 1963.

JoHn J. CzYzaK, Falls Church, Virginia, member since 1950, died February $22,1964$.

Arthur W. Fanta, Manchester, Connecticut, member since 1949, died July 9, 1963.

E. Allen Frost, Evanston, Illinois, member since 1907, died May 17, 1963.

Edward H. Green, New York, N. Y., life member since 1959, died 1963.

Hon. Philis Halpern, Buffalo, New York, member since 1954, died 1964.

E. Brron Hulley, Atlanta, Georgia, member since 1960, died 1963.

J. Francis KICAK, Youngstown, Ohio, member since 1937, died 1963.

Samuel Kuaus, Washington, D. C., member since 1958, died August 1, 1963.

Hon. Herbert H. Lehman, New York, N. Y., member since 1953, died December 5, 1963.

OMar Loutri, New York, N. Y., member since 1949, died May 17, 1963. 
JAMES M. NicelY, New York, N. Y., member since February, 1964, died March 14, 1964.

CarL B. RIX, Milwaukee, Wisconsin, member since 1945, died October 1, 1963.

Geraud E. Schroeder, Detroit, Michigan, member since 1947, died March $19,1963$.

LaURence ARNold TanZer, New York, N. Y., member since 1909, died July. 10, 1963.

Georat A. Weiss, New York, N. Y., member since 1949, died 1963.

Albrecht Marburg Yerkes, Los Angeles, California, member since 1961, died January 20, 1963.

The members rose and observed a moment of silence.

The Chairman called upon Mr. Harky LeRoy Jones to present a memorial to Mr. Henry F. Butler.

Mr. Jones. Henry Butler was returning from New York to Washington on February 5, when he was stricken on the plane and died shortly after. The Society lost a warm friend and a devoted member.

It was my privilege to know Henry as a fellow worker in this Society, as a member of the American, the Inter-American and the International Bar Associations, as a practitioner and as a friend and neighbor in Georgetown.

\section{HENRY F. BUTLER}

Henry Franklin Butler was born in Yonkers, New York, in 1896. He was graduated from Princeton University in 1920, and, afterwards, from Harvard Law School. He began the practice of law in Boston and in 1934 he came to Washington where he formed a partnership with his father, Charles Henry Butler, one of the founders of this Society and its first Corresponding Secretary.

Henry was a member and, for most of its existence, Chairman of the Society's Committee on Finance. His individual efforts brought about the generous gift of Mrs. Benjamin Tillar, which enabled the Society to acquire the Tillar House on Massachusetts Avenue for its permanent headquarters. First, as Chairman of the Committee on Administration and then of the Committee on Tillar House, Henry worked unceasingly with the details of zoning, remodeling and refurnishing to prepare the house for our occupancy.

Henry also gave unsparingly and unselfishly to other professional organizations. He was Assistant Treasurer of the Inter-American Bar Association from 1945 to 1947, and of the International Bar Association from 1947 to 1949. Recently, he was Chairman of the Committee on Treatment of Enemy Property in Wartime, of the Section of International and Comparative Law of the American Bar Association. He was a member of the District of Columbia Bar Association, Bar Association of Boston, Bar Association of the State of Maine, the Association of the Bar of the City of New York, and of the American Judicature Society.

As a Hearing Examiner in the Office of Alien Property of the Depart- 
ment of Justice, I came to have a high regard for the professional ability and integrity of Henry Butler as a practitioner before that Agency. Henry represented the principal of some forty claimants in the most complex and involved proceedings ever tried administratively before that Agency -a proceeding far exceeding in its complexity, legally and factually, the famous Interhandel ease. After some ten years, Henry completed the administrative proceedings successfully and, at the time of his death, was engrossed in preparing the cases for retrial in court.

Tillar House symbolizes for the Society its new era of expanded activity. For Henry Butler, Tillar House is a permanent memorial.

We extend our sympathy to his widow, Estelle Kemper Butler.

Mr. Leonard C. Meerer presented the following memorial to Mr. John J. Czyzak:

\section{JOHN CZYZAR}

The life of John Czyzak exemplifies in many ways the life of modern man in a changing world. He was born in Germany in the first days of World War I. His eultural background was Polish. Those who knew him will remember his sensitive playing of the music of Chopin. $\mathrm{He}$ later came to the United States, and became a citizen of this country in 1929.

Following admission to the Bar in Ohio, John Czyzak practiced law privately for several years. Next he undertook further graduate study at Yale, and commenced the teaching of law. Then in 1951 he embarked on a third career and joined the Office of the Legal Adviser in the Department of State. His early work was in the area of economic affairs, where he became a skilled counselor and practitioner in the law of international trade.

In 1960 John Czyzak was appointed Assistant Legal Adviser for Far Eastern Affairs, in recognition of abilities which went far beyond competence in any one field. He entered upon his new work with spirit and imagination. In 1961 and 1962 he became a principal adviser and architect of the settlement for Laos which was worked out at the year-long conference in Geneva.

During his years of service with the Department of State, John Czyzak also made time to resume teaching - this time to lecture on international law. Early in his career he had contributed articles to legal journals on various private-law subjects. These were followed later by articles on legal order for an occupied nation, on international arbitration, and on the Geneva Accords on Laos.

The Department of State and the American Society have lost a distinguished colleague and valued member in John Czyzak's untimely death on February 22, 1964. He had always a friendly good humor, and a cheerful spirit against every adversity. To a world marked by instability often to the point of confusion, where the outbreak of violence was quite usually a threat, John Czyzak brought gifts of clear thought and reason, of patience and devoted work, of wide understanding of languages, peoples, 
ideas, and trends throughout the world. He was the kind of modern man who is building a better world.

The following memorial was prepared by Mr. Oscar Schachter:

\section{OMAR LOUTFI}

Omar Loutfi, a distinguished member of the Society passed away in New York on May 17, 1963. At the time of his death he was the UnderSecretary for Special Political Affairs at the United Nations and he had previously served for a number of years as the Representative of his Government, first Egypt and then the United Arab Republic, to the United Nations. Mr. Loutfi had a distinguished legal career prior to his appointment to political office. He had served as a judge and then counsellor of the State Council in Egypt and as legal adviser to the United Nations Mission in Libya. U Thant, Secretary General of the United Nations, stated at a memorial ceremony: "Omar Loutfi proved himself to be as successful an international civil servant as he had been in his previous position as Ambassador. His wise counsel stood me in good stead on several important occasions. Perhaps his most important characteristic was his evenness of temper and political realism, which served to guard not only himself, but all of us, against excesses of optimism or pessimism. He had, if I may say so, those qualities of head and heart which an ideal international civil servant should possess. His strength of character, as much as intellect, was responsible for his great popularity and stature, both as a diplomat and as an international civil servant. And for these qualities he commanded the affection and respect of all those who knew him well."

The Chatrman then introduced Justice Roberto Regala of the Supreme Court of the Philippines, a member of the Society since 1929, who delivered the following remarks:

Justice Regala. Mr. President, fellow members of the American Society of International Law :

I feel greatly honored to have been asked to say a few words on the general theme-Causing Compliance with International Law-before such a group of luminaries in international law. I bring the greetings and best wishes, first, of the Philippine Society of International Law for the success of your deliberations.

$I$ have listened with keen interest to the panel discussions on the various topies during the last two days. It is sad to note that, notwithstanding the tremendous progress in science and technology, peace does not prevail in the world today. It seems a great irony, but nevertheless true, that man's progress in the art of war has not been matched by his progress in the art of peace. The move of our Society, therefore, to awaken the world to causing compliance with international law will surely contribute greatly to the maintenance of peace.

We have been witnessing one of the main causes of world disorder today: the disregard of some of the rules of international law. Some of the 